\title{
PERAN SELF-EFFICACY TERHADAP SELF-REGULATED LEARNING PADA MAHASISWA YANG BEKERJA DI MASA PANDEMI COVID-19
}

\author{
Linda Setyowati ${ }^{1}$, Riana Sahrani ${ }^{2}$ \\ ${ }^{1}$ Program Studi Magister Psikologi, Fakultas Psikologi, Universitas Tarumanagara \\ ${ }^{1}$ Sekolah Tinggi Manajemen PPM \\ Email: linda.707209203@stu.untar.ac.id \\ ${ }^{2}$ Fakultas Psikologi, Universitas Tarumanagara \\ Email: rianas@fpsi.untar.ac.id
}

Masuk : 17-07-2021, revisi: 22-10-2021, diterima untuk diterbitkan : 25-10-2021

\begin{abstract}
In December 2019, an outbreak of coronavirus or known as Coronavirus Diseases-19 (COVID-19) first occurred in Wuhan, China. The outbreak is affecting the entire world including Indonesia. Therefore, workers or employees who work in government and private sector carry out almost all work from home or known as work from home (WFH). Not spared with the world of education. Learning is usually done face-to-face, changing to a system in network (online) or online.This affects self-regulation as well as self-confidence that must adapt to the new environment. The purpose of this study was to examine the role of self-efficacy in self-regulated learning in students working during the COVID-19 pandemic. Self-regulated learning is a learning ability that uses aspects of metacognition, motivation, and behavior as persistently as possible, with their means and beliefs to achieve the goals set. Self-efficacy is a person's belief that he or she can carry out a task at a certain level that affects. This research was conducted at College X and the University of X Jakarta. This study involved 232 students who worked during the COVID-19 pandemic. The sampling technique used was the purposive sampling technique. Data analysis was performed using multiple regression (multiple regression) using Statistical Product and Service Solutions (SPSS). The results show that selfefficacy plays a role in self-regulated learning by 9,8\%. It can be concluded that there is a positive role of self-efficacy in self-regulated learning. The higher the self-efficacy, the higher the self-regulated learning.
\end{abstract}

Keywords: Self-efficacy, self-regulated learning, college, COVID-19 pandemic

\begin{abstract}
ABSTRAK
Pada bulan Desember 2019, terjadi sebuah wabah virus Corona atau yang dikenal dengan Coronavirus Diseases-19 (COVID-19) pertama kali terjadi di Wuhan, Cina. Wabah tersebut menyerang seluruh dunia termasuk Indonesia. Oleh sebab itu, para pekerja atau karyawan yang bekerja di pemerintahan dan swasta melaksanakan hampir semua pekerjaan dari rumah atau yang dikenal dengan work from home (WFH). Tak luput dengan dunia pendidikan. Pembelajaran yang biasa dilakukan tatap muka, berubah ke sistem dalam jaringan (daring) atau online. Hal ini berpengaruh pada regulasi diri serta keyakinan diri yang harus beradaptasi dengan lingkungan baru. Tujuan dari penelitian ini adalah untuk melihat peran dari self-efficacy terhadap self-regulated learning pada mahasiswa yang bekerja di masa pandemi COVID-19. Self-regulated learning adalah kemampuan belajar yang menggunakan aspek metakognisi, motivasi, dan perilaku dengan sekuat dan segigih mungkin, dengan cara dan keyakinan sendiri untuk mencapai tujuan yang ditetapkan. Self-efficacy merupakan keyakinan seseorang bahwa dia dapat menjalankan suatu tugas pada suatu tingkat tertentu yang mempengaruhi tingkat pencapaian tugasnya. Penelitian ini dilakukan di Sekolah Tinggi X, dan di Universitas X Jakarta. Penelitian ini melibatkan 232 mahasiswa yang bekerja di masa pandemic COVID-19. Teknik pengambilan sampel menggunakan teknik purposive sampling. Pengolahan data menggunakan regresi linear menggunakan Statistical Product and Service Solutions (SPSS). Hasil penelitian menunjukan bahwa self-efficacy berperan dalam self-regulated learning sebesar 9.8\%. Hal ini dapat disimpulkan bahwa terdapat peran positif selfefficacy terhadap self-regulated learning. Semakin tinggi self-efficacy maka dapat meningkatkan self-regulated learning.
\end{abstract}

Kata Kunci: Self-regulated learning, self-efficacy, mahasiswa, pandemi COVID-19 


\section{PENDAHULUAN \\ Latar Belakang}

Pada bulan Desember 2019, terjadi sebuah wabah virus Corona atau yang dikenal dengan Coronavirus Diseases-19 (COVID-19) pertama kali terjadi di Wuhan, Cina. Pandemi COVID-19 ini menyerang seluruh dunia (Chong et al., 2020). COVID-19 masuk ke Indonesia dimulai bulan Maret 2020. Jumlah masyarakat yang terkena virus ini setiap hari mengalami lonjakan yang signifikan. Kasus kematian tenaga medis akibat COVID-19 di Indonesia merupakan angka tertinggi di dunia (Sari et al., 2020). Para pekerja atau karyawan yang bekerja di pemerintahan dan swasta melaksanakan hampir semua pekerjaan dari rumah atau yang dikenal dengan work from home (WFH). Tak luput dengan dunia pendidikan. Pembelajaran yang biasa dilakukan tatap muka, berubah ke sistem dalam jaringan (daring) atau online. Pembelajaran online dan bekerja secara online sudah hampir dilakukan selama 12 bulan.

Dari hasil survey awal yang dilakukan pada tanggal 13 September 2020 hingga tanggal 15 September 2020 kepada 35 mahasiswa yang sedang melanjutkan studi pasca sarjana sambil bekerja mengatakan bahwa 77,2\% mahasiswa kesulitan membagi waktu antara bekerja dan menyelesaikan tugas kuliah selama masa pandemi. 82,9\% mahasiswa mengatakan work from home atau bekerja dari rumah membuat waktu bekerja semakin padat. Beberapa mahasiswa yang mengikuti survey awal ini juga mengatakan bahwa mereka mengalami kesulitan membagi waktu antara bekerja dengan kuliah dikarenakan kesulitan menyeimbangkan waktu antara bekerja, menjaga anak, keluarga dan juga tugas kuliah. Selain itu, salah satu mahasiswa juga mengatakan kesulitan membagi waktu menyelesaikan tugas kuliah karena harus menyelamatkan bisnisnya agar tidak merumahkan para karyawannya, sehingga harus memberikan waktu yang ekstra untuk pekerjaan.

Salah satu mahasiswa mengatakan bahwa selama pandemi COVID-19 dan WFH, proses belajar dilakukan tanpa tatap muka, sehingga mahasiswa tersebut merasakan pembelajaran dalam perkuliahan kurang maksimal. Selain itu, salah satu mahasiswa juga menyebutkan bahwa situasi di rumah membuat belajar secara online kurang fokus. Serta peralihan pembelajaran secara offline ke online membuat beberapa mahasiswa perlu menyesuaikan cara belajar dan membagi waktu antara belajar dan bekerja.

Selama menjalani pendidikan di perguruan tinggi, mahasiswa menghadapi tantangan dan harus menetapkan tujuan untuk menyelesaikan studi. Memecahkan masalah, bagi mahasiswa adalah salah satu tingkat berpikir yang tinggi karena memerlukan pengalaman yang cukup, pengetahuan yang baik, dan memerlukan keterampilan (Basuki \& Napis, 2019). Untuk menuju tujuan tersebut, tidak hanya memerlukan kemampuan dan kompetensi saja, tetapi mahasiswa juga membutuhkan pengaturan diri (Sari \& Arjanggi, 2019).

Keterampilan atau kemampuan memecahkan masalah berkaitan dengan regulasi diri (selfregulation). Zimmerman (dalam Basuki \& Napis, 2019) mengatakan bahwa self-regulation mengacu pada proses untuk memfokuskan pikiran, tindakan sistematis, perasaan, pada pencapaian sebuah tujuan. Regulasi diri juga dapat diartikan sebagai upaya mengelola diri sendiri dalam suatu aktivitas dengan menggunakan kemampuan metakognisi, motivasi, dan perilaku aktif (Ghufron \& Risnawati, 2016). 
Bandura (dalam Usher \& Pajares, 2007) mengatakan bahwa self-efficacy dan self-regulated learning berhubungan erat pada area pendidikan. Self-regulated learning mengacu pada kemampuan siswa untuk mendiagnosis kebutuhan belajar, menetapkan tujuan, memilih sumber daya, dan mengevaluasi diri (Chen et al., 2019). Pintrich dan De Groot (dalam Wolter, 2003) mengatakan dalam penelitiannya bahwa peserta didik yang menggunakan self-regulated learning menunjukan prestasi, motivasi dan self efficacy yang lebih tinggi.

Mahasiswa yang bekerja, selain harus menyelesaikan pekerjaannya juga harus fokus dalam melaksanakan tugas pendidikannya, sehingga menanggung dua tanggung jawab secara bersamaan. Mahasiswa yang bekerja seharusnya memiliki kesiapan diri, mental dan regulasi diri agar proses pekerjaan dan perkuliahan berjalan dengan baik. Mahasiswa diharapkan memiliki kesadaran terhadap tugas-tugas yang dimiliki. Kesadaran inilah yang menuntun mereka untuk mengontrol, mengarahkan dan mengatur perilakunya dalam belajar (Mu'min, 2016).

Zimmerman (1989) mengatakan self-regulated learning juga dipengaruhi oleh tiga faktor utama, yaitu keyakinan diri (self-efficacy), motivasi dan tujuan. Dalam proses pembelajaran, perlu keyakinan dari peserta didik jika akan memahami, mengerti dan bahkan mampu memahami materi pembelajaran yang dalam istilah disebut self efficacy perilaku (Cheng, 2011). Santrock (2009) mengatakan self-efficacy adalah keyakinan seseorang tentang kemampuan melakukan tugas, berprestasi, mencapai tujuan dan rencana tindakan untuk mencapai tujuan. Bandura (1997) mengatakan bahwa Self-efficacy adalah apersepsi yang dapat dibentuk dengan menginterpretasikan informasi dari pengalaman yang otentik sebagai sumber yang sangat berpengaruh. Bandura (1997) Mengatakan bahwa self efficacy tidak sama dengan seberapa besar seseorang menyukai tugas yang dihadapi, tetapi lebih terkait dengan seberapa besar seseorang dapat meyakini dirinya dapat berhasil pada bidang tertentu.

\section{Rumusan Masalah}

Rumusan permasalahan dan pertanyaan penelitian yang diangkat pada penelitian ini adalah apakah self-efficacy berperan pada self-regulated learning pada mahasiswa yang bekerja di masa pandemi COVID-19?

\section{METODE PENELITIAN}

Partisipan dalam penelitian ini adalah mahasiswa yang bekerja atau pada mahasiswa kelas eksekutif. Penelitian ini menggunakan teknik pengambilan sampel dengan purposive sampling karena pada penelitian ini, peneliti memilih partisipan berdasarkan pertimbangan dan kriteria tertentu yaitu mahasiswa yang bekerja. Jumlah sampel dalam penelitian ini adala sebanyak 232 orang mahasiswa yang bekerja. Pengambilan data dilakukan dengan penyebaran kuesioner dalam jaringan (online) dan dilakukan juga secara online. Penelitian ini berjenis kuantitatif korelasional. Penelitian ini menganalisis peran Self-efficacy terhadap self-regulated learning pada mahasiswa yang bekerja di masa pandemic COVID-19. Sementara itu metode regresi digunakan untuk menguji hipotesis.

\section{Instrumen Penelitian}

Alat ukur yang digunakan pada penelitian ini adalah Academic Self-regulated learning Scale berdasarkan teori Zimmerman dan Martinez-Pons yang diadaptasi oleh Andiani (2017) ke Bahasa Indonesia oleh dengan nilai reliabilitas $(\alpha=0,953)$. Angket A-SRL-S dalam penelitian ini memiliki 54 butir favourable dan memiliki empat kategori respon (Sangat Setuju, Setuju, Tidak Setuju, dan Sangat Tidak Setuju). 
Untuk mengukur self-efficacy adalah General Self-efficacy Scale yang telah diadaptasi ke Bahasa Indonesia oleh Novrianto et al. (2019) berdasarkan teori Bandura. General Self-efficacy Scale Bahasa Indonesia ini memiliki nilai Alpha Cronbach $(\alpha)=0,865$ dan bermuatan faktor positif dan terdiri dari 10 aitem. Bentuk alat ukur ini adalah skala likert dengan kategori respon STS (Sangat Tidak Sesuai), TS (Tidak Sesuai), N (Netral), CS (Cukup Sesuai), SS (Sangat Sesuai).

\section{HASIL DAN PEMBAHASAN}

\section{Gambaran Data Demografi}

Jumlah sampel dalam penelitian ini adala sebanyak 232 orang mahasiswa yang bekerja. Jumlah partisipan yang berjenis kelamin perempuan adalah sebanyak 103 orang dan yang berjenis kelamin laki-laki sebanyak 129 partisipan. Partisipan yang sedang menempuh pendidikan S2 terdapat 171 orang atau $73,71 \%$. Sedangkan $26,29 \%$ lainnya adalah mahasiswa S1 yang terdiri dari 61 orang. Apabila dilihat dari jurusan pendidikan, jumlah subjek pada jurusan Manajemen sebanyak 197 orang atau 84,89\%, jurusan Psikologi sebanyak 25 orang atau 10,77\%, jurusan perpajakan sebanyak 1 orang atau 0,43\%, dan jurusan Akuntansi sebanyak 9 orang atau 3,88\%.

\section{Gambaran Variabel Penelitian}

Self-regulated learning memiliki Mean hipotetik 135 sedangkan mean empiric 162,50 dengan standar deviasi 21,459. Dari pengkategorian yang telah dilakukan partisipan pada penelitian ini masuk dalam kategori tinggi dengan frekuensi sebanyak 141 partisipan atau sebanyak $60.8 \%$. Pada data yang didapatkan mean empirik lebih besar daripada mean hipotetik menandakan bahwa selfregulated learning partisipan berada pada kategori tinggi.

Gambaran data untuk Self-efficacy memiliki Mean hipotetik 30 sedangkan mean empiric 40,63 dengan standar deviasi 5,191. Kategori rendah pada self-efficacy memiliki nilai $<24.81$ sedangkan kategori tinggi memiliki nilai $>35.19$. Dari pengkategorian yang telah dilakukan partisipan pada penelitian ini masuk dalam kategori tinggi dengan frekuensi sebanyak 202 partisipan atau sebanyak $87 \%$. Pada data yang didapatkan mean empirik lebih besar daripada mean hipotetik menandakan bahwa self-efficacy partisipan berada pada kategori tinggi.

\section{Hasil Penelitian}

Hasil estimasi model regresi pengaruh kesadaran self-efficacy $(\mathrm{X})$ terhadap self-regulated learning (Y) dapat dilihat melalui tabel 3.1 di bawah ini:

\section{Tabel 1}

\section{Hasil Uji Regresi}

\begin{tabular}{|c|c|c|c|c|}
\hline \multicolumn{5}{|c|}{ Model Summary } \\
\hline Model & $\mathrm{R}$ & R Square & Adjusted R Square & $\begin{array}{l}\text { Std. Error of the } \\
\text { Estimate }\end{array}$ \\
\hline 1 & $.314^{\mathrm{a}}$ & .098 & .094 & 18.65368 \\
\hline
\end{tabular}


Besarnya kontribusi pengaruh self-efficacy (X) terhadap self-regulated learning (Y) dapat diketahui melalui koefisien determinasinya $\left(\mathrm{R}^{2}\right)$ pada Tabel 3.1 yaitu sebesar 0.098 . Hal ini berarti self-regulated learning dapat dijelaskan oleh self-efficacy sebesar 9.8\%, sedangkan sisanya sebesar $90.2 \%$ merupakan kontribusi dari faktor lain yang tidak dibahas dalam penelitian ini.

\section{Tabel 2}

Hasil Uji $t$

\begin{tabular}{|c|c|c|c|c|c|c|}
\hline \multicolumn{7}{|c|}{ Coefficients $^{\mathbf{a}}$} \\
\hline \multirow[t]{2}{*}{ Model } & & \multicolumn{2}{|c|}{ Unstandardized Coefficients } & \multirow{2}{*}{$\begin{array}{c}\begin{array}{c}\text { Standardized } \\
\text { Coefficients }\end{array} \\
\text { Beta }\end{array}$} & \multirow[t]{2}{*}{$\mathrm{t}$} & \multirow[t]{2}{*}{ Sig. } \\
\hline & & $\mathrm{B}$ & Std. Error & & & \\
\hline \multirow[t]{2}{*}{1} & (Constant) & 117.901 & 9.167 & & 12.861 & .000 \\
\hline & $\mathrm{X}$ & 1.114 & .223 & .314 & 5.007 & .000 \\
\hline
\end{tabular}

a. Dependent Variable: Y

Hasil pengujian menghasilkan $\mathrm{t}$ hitung sebesar 5.007 dengan $\mathrm{p}$ value sebesar 0.000 . Hasil pengujian tersebut menunjukkan $p$ value $(0.000)<$ level of significance $(\alpha=0.05)$ sehingga terdapat pengaruh yang signifikan self-efficacy terhadap self-regulated learning. Koefisien regresi $\beta$ bernilai positif sebesar 1.114. Hal ini berarti terdapat peran positif self-efficacy terhadap selfregulated learning, hal ini berarti semakin tinggi self-efficacy maka dapat meningkatkan selfregulated learning.

Berdasarkan hasil penelitian ini dihasilkan bahwa self-efficacy dapat berperan terhadap selfregulated learning pada mahasiswa yang bekerja di masa pandemi COVID-19. Sejalan dengan Schunk dan Meece (2005) efikasi diri membantu mahasiswa untuk meyakinkan diri untuk terus belajar dan melakukan tindakan di setiap tahapan. Dengan adanya efikasi diri mahasiswa lebih mudah menganalisa situasi dan masalah, sehingga dapat mengambil tindakan efektif untuk membuat jalan keluar. Efikasi diri mempengaruhi mahasiswa untuk menyelesaikan masalah, mencari tahu tingkat kesulitan, keyakinan menyelesaikan tugas dan keyakinan terhadap proses mencapai hasil. Dengan adanya efikasi diri mahasiswa dapat dengan percaya diri menetapkan tolak ukur untuk menyelesaikan tugas, mengidentifikasi tugas, dan bertanggung jawab atas kemajuan diri sendiri (Schunk \& Meece, 2005).

Bandura (1997) mengemukakan dimensi self-efficacy terdiri dari magnitude, strength, dan generality. Magnitude berkaitan dengan kesulitan tugas, strength berkaitan dengan ketahanan individu, dan generality berkaitan dengan luas bidang keyakinan individu (Bandura, 1997). Dimensi yang berkaitan erat dengan proses pembelajaran adalah dimensi magnitude dan strength. Apabila mahasiswa memiliki tingkat magnitude dan strength yang baik dalam dirinya akan mendorong mahasiswa tersebut untuk tetap fokus dalam proses pembelajaran.

Lianto (2019) mengatakan bahwa pengalaman yang berhasil adalah pemicu utama terhadap selfefficacy. Keberhasilan kecil pada mahasiswa di masa lalu akan mendorong mahasiswa tersebut lebih percaya akan kemampuannya dan mendorong mahasiswa untuk berupaya mengukir keberhasilan lain. Oktariani (2018) mengatakan mahasiswa membutuhkan keuletan jasmani dan rohani agar dapat melalui seluruh hambatan dan kesulitan pada saat proses belajar. Untuk memupuk keuletan tersebut, mahasiswa hendaknya memandang segala kesulitan sebagai tantangan yang harus diatasi dan dihadapi bukan sebagai alasan untuk menyerah. 
Bandura (1997) mengatakan untuk meningkatkan self-efficacy dapat dilakukan dengan cara memandang masalah sebagai tantangan untuk dipecahkan, memiliki komitmen yang kuat untuk mencapai tujuan yang telah ditetapkan, memandang umpan balik sebagai sarana memperbaiki diri, dan memandang kegagalan sebagai hasil dari kurangnya usaha atau pengetahuan bukan karena kurangnya bakat. Kristiyani (2020) mengatakan dengan memiliki dan meningkatkan self-efficacy dapat mempengaruhi performansi dalam belajar dalam proses kognitif, motivasional, afektif dan seleksi.

Mahasiswa yang sudah berupaya atau memiliki efikasi diri yang baik akan mempengaruhi cara mahasiswa itu dalam mempersepsi hasil belajarnya. Mahasiswa tersebut dapat mengetahui apakah pengetahuan yang sudah dimilikinya sudah cukup atau belum. Self-efficacy juga akan mendorong motivasi internal untuk meningkatkan kesiapan dan untuk meluangkan usaha dalam belajar, sehingga menjaga mahasiswa tersebut tetap bertahan ketika menghadapi masalah dan membantu bangkit kembali lebih cepat apabila mengalami kegagalan. Proses kognitif dan motivasional tersebut membantu mahasiswa untuk menyiapkan strategi terbaik dalam belajar, dan mempengaruhi proses persiapan pada self-regulated learning.

Persepsi yang kuat terkait kemampuan yang dimiliki akan mengurangi kecemasan dan juga stress pada diri mahasiswa. Hal ini dapat menjaga efektivitas fungsi kognitif dan intelegensi. Tahapan ini berkaitan dengan proses pelaksanaan dalam self-regulated learning. Self-efficacy juga berkaitan dengan proses seleksi, dimana akan mempengaruhi keputusan dan jenis pilihan yang akan diambil oleh mahasiswa dalam proses pembelajaran. Bandura (1997) mengatakan bahwa faktor yang mempengaruhi self-efficacy adalah budaya, gender, sifat dari tugas yang dihadapi, intensif eksternal, status atau peran individu dalam lingkungan, dan informasi tentang kemampuan diri.

\section{KESIMPULAN DAN SARAN}

Hasil dari penelitian dapat disimpulkan bahwa self-efficacy berperan terhadap self-regulated learning pada mahasiswa yang bekerja di masa pandemic COVID-19 sebesar 9,8\%. Sementara sisanya dijelaskan oleh variabel lainnya yang tidak ada dalam penelitian ini.

Saran untuk penelitian selanjutnya diharapkan dapat menggunakan sampel perguruan tinggi lainnya yang ada di Indonesia sehingga gambaran penelitian dapat lebih luas. Penelitian ini dapat dilakukan untuk berbagai jenjang pendidikan pada mahasiswa baik mahasiswa S1, S2, maupun mahasiswa yang sedang menempuh pendidikan S3. Penelitian selanjutnya juga dapat membandingkan self-regulated learning pada mahasiswa yang bekerja dan mahasiswa yang tidak bekerja.

Saran praktis untuk mahasiswa yang sedang bekerja sebaiknya meningkatkan self-efficacy yang dimiliki. Meningkatkan self-efficacy dapat dilakukan dengan memandang masalah sebagai tantangan untuk dipecahkan, menumbuhkan dan menanamkan komitmen yang kuat dalam mencapai tujuan yang ditetapkan, memandang umpan balik atau masukan sebagai perbaikan diri, memandang kegagalan sebagai hasil dari kurangnya usaha dan pengetahuan bukan karena kurangnya bakat yang dimiliki, dan meningkatkan usaha ketika mengalami kegagalan.

Mahasiswa juga dapat memetakan materi perkuliahan yang sudah dipahami dan yang belum dipahami. Mahasiswa dapat membaca buku atau jurnal secara mandiri atau berlatih soal-soal. Mahasiswa juga bisa belajar melalui video, sharing dan berdiskusi dengan dosen dan teman sebayanya. Belajar dari pengalaman teman sebaya atau orang lain juga dapat meningkatkan 
pengetahuan dan efikasi diri. Saling memberi dukungan dengan teman juga akan membantu meningkatkan efikasi diri. Mahasiswa juga tidak lupa untuk selalu berdoa dan berusaha. Dengan memiliki self-efficacy yang baik, maka mahasiswa akan memiliki regulasi belajar yang baik pula.

\section{Ucapan Terima Kasih (Acknowledgement)}

Peneliti mengucapkan terima kasih kepada Sekolah Tinggi X yang telah memberikan izin kepada peneliti untuk melakukan pengambilan data. Peneliti juga mengucapkan terima kasih kepada seluruh partisipan dan pihak yang telah membantu dan mendukung dalam proses penelitian ini.

\section{REFERENSI}

Andiani, S. (2017). Hubungan prestasi akademik dan strategi regulasi diri dalam belajar pada mahasiswa tunarungu. Calyptra: Jurnal Ilmiah Mahasiswa Universitas Surabaya, 6(2).

Bandura, A. (1997). Self-efficacy: The exercise of control. W.H Freeman and Company.

Basuki, K. H., \& Napis, N. (2019). Analisis pemecahan masalah fisika mahasiswa ditinjau dari regulasi diri, adversity quotient, dan efikasi diri. Diskusi Panel Nasional Pendidikan Matematika, 5(1).

Chen, J. H., Björkman, A., Zhou, J. H., \& Engström, M. (2019). Self-regulated learning ability, metacognitive ability, and general self-efficacy in a sample of nursing students: A crosssectional and correlational study. Nurse Education in Practice, 37. https://doi.org/10.1016/j.nepr.2019.04.014

Cheng, E. C. K. (2011). The role of self-regulated learning in enhancing learning performance. The International Journal of Research and Review, 6(1), 1-16.

Chong, Y. Y., Chien, W. T., Cheng, H. Y., Chow, K. M., Kassianos, A. P., Karekla, M., \& Gloster, A. (2020). The role of illness perceptions, coping, and self-efficacy on adherence to precautionary measures for COVID-19. International Journal of Environmental Research and Public Health, 17(18), 6540.

Ghufron, M. N., \& Risnawati, R. (2016). Teori-teori psikologi. Ar-Ruzz Media

Kristiyani, T. (2020). Self-regulated learning: Konsep, implikasi dan tantangannya bagi siswa di Indonesia. Sanata Dharma University Press.

Lianto, L. (2019). Self-efficacy: A brief literature review. Jurnal Manajemen Motivasi, 15(2), 5561.

Mu'min, S. A. (2016). Regulasi diri dalam belajar mahasiswa yang bekerja. Al-Ta'dib, 9(1), 1-20.

Novrianto, R., Marettih, A. K. E., \& Wahyudi, H. (2019). Validitas konstruk instrumen general self-efficacy scale versi Indonesia. Jurnal Psikologi, 15(1), 1-9.

Oktariani, O. (2018). Peranan self-efficacy dalam meningkatkan prestasi belajar siswa. Jurnal Psikologi Kognisi, 3(1), 41-50.

Sari, H. R., \& Arjanggi, R. (2019). Peran efikasi diri dan dukungan sosial teman sebaya terhadap belajar berdasar regulasi diri pada mahasiswa universitas islam sultan agung Semarang. Proyeksi, 14(1), 53-62.

Sari, S. P., Aryansah, J. E., \& Sari, K. (2020). Resiliensi mahasiswa dalam menghadapi pandemi covid 19 dan implikasinya terhadap proses pembelajaran. Indonesian Journal of Guidance and Counseling: Theory and Application, 9(1), 17-22.

Schunk, D. H., \& Meece, J. L. (2005). Self-efficacy development in adolescents. University of Kentucky.

Usher, E. L., \& Pajares, F. (2007). Self-efficacy for self-regulated learning. Educational and Psychological Measurement, 68(3), 443-463. https://doi.org/10.1177/0013164407308475 
Wolters, C. A., Pintrich, P. R., \& Karabenick, S. A. (2003). Assessing academic self-regulated learning. Conference on Indicator of Positive Development: Definitions, Measures, and Prospective Validity. https://childtrends.org/wp-content/uploads/2013/05/Child_Trends2003_03_12_PD_PDConfWPK.pdf

Zimmerman, B. J. (1989). A social cognitive view of self-regulated academic learning. Journal of Educational Psychology, 81, 329-339. 